\title{
Nonlinear response of modelled stratospheric ozone to changes in greenhouse gases and ozone depleting substances in the recent past
}

\author{
S. Meul, S. Oberländer-Hayn, J. Abalichin, and U. Langematz \\ Institut für Meteorologie, Freie Universität Berlin, Berlin, Germany \\ Correspondence to: S. Meul (stefanie.meul@met.fu-berlin.de)
}

Received: 06 February 2015 - Published in Atmos. Chem. Phys. Discuss.: 27 March 2015

Revised: 03 June 2015 - Accepted: 08 June 2015 - Published: 24 June 2015

\begin{abstract}
In the recent past, the evolution of stratospheric ozone $\left(\mathrm{O}_{3}\right)$ was affected by both increasing ozone depleting substances (ODSs) and greenhouse gases (GHGs). The impact of the single forcings on $\mathrm{O}_{3}$ is well known. Interactions between the simultaneously increased GHG and ODS concentrations, however, can occur and lead to nonlinear $\mathrm{O}_{3}$ changes. In this study, we investigate if nonlinear processes have affected $\mathrm{O}_{3}$ changes between 1960 and 2000. This is done with an idealised set of time slice simulations with the chemistry-climate model EMAC. Due to nonlinearity the past ozone loss is diminished throughout the stratosphere, with a maximum reduction of $1.2 \%$ at $3 \mathrm{hPa}$. The total ozone column loss between 1960 and 2000 that is mainly attributed to the ODS increase is mitigated in the extra-polar regions by up to $1.1 \%$ due to nonlinear processes. A separation of the $\mathrm{O}_{3}$ changes into the contribution from chemistry and transport shows that nonlinear interactions occur in both. In the upper stratosphere a reduced efficiency of the $\mathrm{ClO}_{x}$ catalysed $\mathrm{O}_{3}$ loss chiefly causes the nonlinear $\mathrm{O}_{3}$ increase. An enhanced formation of halogen reservoir species through the reaction with methane $\left(\mathrm{CH}_{4}\right)$ reduces the abundance of halogen radicals significantly. The temperature-induced deceleration of the $\mathrm{O}_{3}$ loss reaction rate in the Chapman cycle is reduced, which leads to a nonlinear $\mathrm{O}_{3}$ decrease and counteracts the increase due to $\mathrm{ClO}_{x}$. Nonlinear effects on the $\mathrm{NO}_{x}$ abundance cause hemispheric asymmetric nonlinear changes of the $\mathrm{O}_{3}$ loss. Nonlinear changes in $\mathrm{O}_{3}$ transport occur in particular in the Southern Hemisphere ( $\mathrm{SH}$ ) during the months September to November. Here, the residual circulation is weakened in the lower stratosphere, which goes along with a reduced $\mathrm{O}_{3}$ transport from the tropics to high latitudes. Thus, $\mathrm{O}_{3}$ decreases in the $\mathrm{SH}$ polar region but increases in the SH midlatitudes. The existence of nonlinearities implies that
\end{abstract}

future ozone change due to ODS decline slightly depends on the prevailing GHG concentrations. Therefore the future ozone evolution will not simply be a reversal of the past.

\section{Introduction}

During the 20th century both the emissions of ozone depleting substances (ODSs) and greenhouse gases (GHGs) increased, which had a large effect on stratospheric ozone $\left(\mathrm{O}_{3}\right)$ (e.g. WMO, 2007). Observations show that between 1979 and 2000 the total column ozone decreased by 2$3 \% /$ decade at midlatitudes in the annual mean and by up to $12 \% /$ decade in the Southern Hemisphere $(\mathrm{SH})$ polar region in spring (e.g. Fioletov et al., 2002). This development was mainly caused by increasing concentrations of ODSs (e.g. WMO, 2007). As these compounds are relatively chemically inert in the troposphere, they are transported into the stratosphere where they are decomposed, releasing reactive chlorine and bromine compounds at levels well above the natural background concentrations. The chlorine and bromine radicals can then initiate catalytic reaction cycles which destroy ozone (e.g. Molina and Rowland, 1974). In the polar regions in spring, this catalytic ozone loss is especially effective since the occurrence of polar stratospheric clouds in winter leads to an enhanced conversion of halogen reservoir species to radicals (e.g. Solomon et al., 1986).

Increasing concentrations of the well-mixed GHGs carbon dioxide $\left(\mathrm{CO}_{2}\right)$, methane $\left(\mathrm{CH}_{4}\right)$ and nitrous oxide $\left(\mathrm{N}_{2} \mathrm{O}\right)$ affect the ozone evolution in addition to the ODS-induced changes by different mechanisms. They change the radiative budget of the atmosphere and therefore cool the stratosphere (e.g. IPCC, 1996). This decelerates the Chapman $\mathrm{O}_{3}$ loss 
reaction, $\mathrm{O}_{3}+\mathrm{O}$, and accelerates the reaction $\mathrm{O}_{2}+\mathrm{O}+M$, which controls the partitioning of $\mathrm{O}_{x}\left(=\mathrm{O}+\mathrm{O}_{3}\right)$, and hence increases ozone (e.g. Rosenfield et al., 2002; Jonsson et al., 2004). At the same time, the temperatures of the troposphere and of the oceans increase. This warming alters the stratospheric meridional residual circulation (Brewer-Dobson circulation, BDC) (e.g. Garny et al., 2011a; Oberländer et al., 2013) and therefore the transport of ozone and other chemical species such as chlorine source gases (e.g. Butchart and Scaife, 2001; Cook and Roscoe, 2012). Increased emissions of $\mathrm{CO}_{2}, \mathrm{CH}_{4}$ and $\mathrm{N}_{2} \mathrm{O}$ lead to changes in the stratospheric $\mathrm{NO}_{x}\left(=\mathrm{NO}+\mathrm{NO}_{2}\right)$ (e.g. Rosenfield and Douglass, 1998) and $\mathrm{HO}_{x}\left(=\mathrm{OH}+\mathrm{HO}_{2}\right)$ abundances (e.g. LeTexier et al., 1988) and also modify chemical ozone loss (e.g. Portmann et al., 2007; Revell et al., 2012). Furthermore, the chemical production of $\mathrm{O}_{3}$ via $\mathrm{CH}_{4}$ oxidation is increased in the lower stratosphere (e.g. Johnston and Podolske, 1978; Nevison et al., 1999), while the chemical $\mathrm{O}_{3}$ production through photolysis is decreased due to the reversed "self-healing" effect (e.g. Portmann et al., 2007).

Former studies have analysed the contributions from increasing GHG and ODS concentrations to the past ozone change. So far, observational time series have been too short to clearly separate the effects using multiple linear regression (Stolarski et al., 2010). Therefore, simulations with chemistry-climate models (CCMs) are used for attribution studies. Different strategies for the attribution are discussed in McLandress et al. (2010), ranging from the multiple linear regression analysis of a single transient simulation including all forcings (e.g. Oman et al., 2010) to the comparison of a set of simulations with different forcings (e.g. Waugh et al., 2009). Differences among the studies arise also from the explanatory variables that are used as proxy for the GHG effect (e.g. temperature or $\mathrm{CO}_{2}$ ) and the processes that are considered (e.g. including composition changes by $\mathrm{CH}_{4}$ and $\mathrm{N}_{2} \mathrm{O}$ increases). However, qualitatively all studies agree and consistently show that increasing ODSs are the dominant driver of past ozone loss, while the GHG increase has led to an ozone increase in the upper stratosphere (e.g. Waugh et al., 2009; Oman et al., 2010; Shepherd and Jonsson, 2008; Jonsson et al., 2009).

Since both GHG and ODS abundances have increased simultaneously in the atmosphere, interactions between the forcings may occur (e.g. Cicerone et al., 1983; Yang and Brasseur, 2001). In most attribution studies, however, those nonlinear interactions, or buffering effects, are not considered, either by simply assuming linearity (e.g. Jonsson et al., 2009) or by using explanatory variables that can be affected by nonlinear processes themselves (e.g. the temperature or the abundance of stratospheric halogen radicals; Jonsson et al., 2009; Nevison et al., 1999, respectively).

The effects of nonlinearities on ozone were analysed by Haigh and Pyle (1982) by simultaneously changing ODS and GHG concentrations. They used four experiments with a two-dimensional circulation model: a control run with low
$\mathrm{CO}_{2}$ concentrations and without chlorine chemistry, a run with increasing levels of $\mathrm{CO}_{2}$ and without chlorine chemistry, a run with low $\mathrm{CO}_{2}$ concentrations and high ODS concentrations and a run with increasing levels of $\mathrm{CO}_{2}$ and high ODS levels. With this set of simulations it is possible to detect nonlinear effects. Haigh and Pyle (1982) found that the ozone changes in the upper stratosphere caused by the coupled perturbation are not equal to the sum of the individual changes. The ozone decrease due to the combined forcing is larger than the ozone decrease expected from the sum of the ODS and the GHG effect. For total column ozone, they reported a decrease from 1960 values by $3.2 \%$ due to an ODS increase to predicted 2000 levels. Total column ozone is increased by $3 \%$ due to an increase of the $\mathrm{CO}_{2}$ content from 320 to $400 \mathrm{ppm}$, a value slightly higher than actually observed in the year 2000 . The combined forcing results in a change of $-0.6 \%$ (compared to $-0.2 \%$ in the sum). They explained the nonlinearity with a reduced temperature dependency of ozone and therefore a reduced positive effect of the GHGs if chlorine chemistry were considered.

A detailed analysis of nonlinear buffering effects between increasing halogen and GHG concentrations is reported in Nevison et al. (1999). They analysed the effect of simultaneously increased concentrations of halogens, $\mathrm{CH}_{4}$ and $\mathrm{N}_{2} \mathrm{O}$ on the $\mathrm{NO}_{x}, \mathrm{HO}_{x}$ and halogen-catalysed ozone loss in model simulations. They found that increasing $\mathrm{CH}_{4}$ together with the halogen concentrations mitigates the halogen-catalysed $\mathrm{O}_{3}$ loss, since the reaction $\mathrm{CH}_{4}+\mathrm{Cl}$ leads to the formation of the reservoir species $\mathrm{HCl}$ and thus to a reduced $\mathrm{ClO}_{x} / \mathrm{Cl}_{y}$ ratio. Furthermore, increasing $\mathrm{N}_{2} \mathrm{O}$ and hence $\mathrm{NO}_{x}$ causes a buffering of the $\mathrm{HO}_{x}$ and halogen-catalysed $\mathrm{O}_{3}$ loss through the formation of the reservoir species $\mathrm{HNO}_{3}, \mathrm{ClONO}_{2}$ and $\mathrm{BrONO}_{2}$.

Since both GHGs and ODSs affect the temperature of the stratosphere, nonlinear changes in the temperature structure can have an impact on wave propagation and hence on the residual mean circulation. This is analysed in detail in McLandress et al. (2010). The study is based on a set of transient simulations with the CCM CMAM, which allows the identification of a nonlinear response to ODS and the radiative effect of GHG changes. The additivity is tested by comparing the long-term trends from the sum of the experiments with either ODSs or GHGs fixed with the trends from the simulation with both changing GHGs and ODSs. They state that the response in the zonal mean temperature, zonal mean zonal wind and the mass flux in SH spring and summer is linear within the statistical uncertainty.

For future ozone changes, the issue of additivity is briefly addressed in the study by Zubov et al. (2013) who analysed a set of time slice simulations with the CCM SOCOL focusing on the future role of GHG, ODS and sea surface temperatures (SSTs)/sea ice concentrations (SICs) forcing. They find positive nonlinear annual mean ozone changes in the tropical upper stratosphere and the SH polar lower stratosphere. However, the underlying processes are not discussed. 
Table 1. Boundary conditions for the four time slice simulations indicated by the year of the input time series.

\begin{tabular}{lcccc}
\hline & R1960 & R2000 & GHG2000 & ODS2000 \\
\hline GHGs & 1960 & 2000 & 2000 & 1960 \\
SSTs/SICs & $1955-1964$ mean & $1995-2004$ mean & $1995-2004$ mean & $1955-1964$ mean \\
ODSs & 1960 & 2000 & 1960 & 2000 \\
Ozone precursors & 1960 & 2000 & 2000 & 1960 \\
\hline
\end{tabular}

In this study we want to address the question of the relevance of nonlinear processes in ozone chemistry and transport in the recent past. We aim to clarify if ozone evolution was affected by nonlinear interactions between the increasing concentrations of well-mixed GHGs and ODSs. Therefore, we want to consider the effects of both changing temperature and chemical composition and account for nonlinear changes in all processes. This is realised with the help of an idealised set of multi-year equilibrium simulations with a state-of-the-art CCM following the strategy by Zubov et al. (2013). The advantage of time slice simulations compared to transient experiments is the improved statistical basis, which allows the detection of small signals. In these simulations we detect and quantify the contribution of nonlinearities to the ozone change between 1960 and 2000 and analyse the processes leading to the nonlinearities.

The study is composed as follows. In Sect. 2 the model and the experiments used in this study are described. The results are discussed in Sect. 3 , followed by a summary and conclusion in Sect. 4.

\section{Model and experimental setup}

A set of equilibrium simulations has been performed with the ECHAM/MESSy Atmospheric Chemistry (EMAC) CCM version 1.7 (Jöckel et al., 2006). The core atmospheric model is ECHAM5 (the fifth generation European Centre Hamburg general circulation model; Roeckner et al., 2006). Via the Modular Earth Submodel System (MESSy1) the core model is coupled to the atmospheric chemistry module MECCA1 (Module Efficiently Calculating the Chemistry of the Atmosphere; Sander et al., 2005) and to a standard set of submodels describing tropospheric and middle atmosphere processes. Additionally, the highly resolved short-wave radiation parameterisation FUBRad (Nissen et al., 2007) is used. The model is run with horizontal resolution T42 (corresponding to a quadratic Gaussian grid of approx. $2.8^{\circ} \times 2.8^{\circ}$ ) and 39 hybrid model layers between the surface and $0.01 \mathrm{hPa}$ $(\sim 80 \mathrm{~km})$. Since this model version is not coupled to an ocean model, the SSTs and SICs are prescribed. After a spinup period ( 2 years with previous scaling of the initial concentrations of long-lived chemical substances), each experiment has been integrated for 40 years.

The performance of the EMAC model in this configuration has been evaluated in different model intercomparison studies (e.g. Austin et al., 2010; Eyring et al., 2010) with respect to the ozone evolution. EMAC is within the range of other CCMs, but the observed ozone depletion in the Antarctic spring is not fully captured by simulations with EMAC.

To analyse the additivity of the ozone response to the GHG and ODS forcing between 1960 and 2000, four time slice simulations are required analogous to Haigh and Pyle (1982) and Zubov et al. (2013): two simulations that represent the reference states of the atmosphere for the year 1960 (R1960) and the year 2000 (R2000), with observed mixing ratios of well-mixed GHGs $\left(\mathrm{CO}_{2}, \mathrm{CH}_{4}, \mathrm{~N}_{2} \mathrm{O}\right)$ from the IPCC (2001) and the ODSs from the WMO (2007) for the corresponding years, and two simulations in which just the GHG (GHG2000) or the ODS (ODS2000) boundary conditions are set to present day conditions while the other is kept at 1960 levels. The RETRO (REanalysis of the TROpospheric chemical composition) data set (Schultz et al., 2007) is used for the emissions of tropospheric ozone precursors. The SSTs and SICs from a transient simulation with the coupled atmosphere ocean model ECHAM5/MPIOM (Max Planck Institute ocean model; Jungclaus et al., 2006) are prescribed as 10-year averages for the period 1955-1964 in the R1960 and ODS2000 simulations and for the period 1995-2004 for the R2000 and the GHG2000 simulations. Therefore, there is no variability due to ENSO in the prescribed SSTs/SICs time series. Other natural forcings such as solar variability, the quasi-biennial oscillation (QBO) or volcanic eruptions are not included either. In all experiments, mean conditions of the 11-year solar cycle are prescribed using the average of the spectral solar flux between the minimum and the maximum of solar cycle 22. Since no QBO nudging is applied, easterly winds prevail in the tropical stratosphere. For reference, the specific boundary conditions used for the simulations are listed in Table 1.

The response of ozone to the combined GHG and ODS forcing is determined by calculating the difference between the mean states of the R2000 and the R1960 simulations (total $=\mathrm{R} 2000-\mathrm{R} 1960$ ). With the help of the simulations GHG2000 and ODS2000 we can separate the effects due to GHGs $(\mathrm{GHG}=\mathrm{GHG} 2000-\mathrm{R} 1960)$ and due to ODSs only $(\mathrm{ODS}=\mathrm{ODS} 2000-\mathrm{R} 1960)$. To test the additivity a nonlinear contribution is calculated:

nonlinear $=$ total $-(\mathrm{GHG}+\mathrm{ODS})$. 
It has to be noted that changes in tropospheric ozone due to changes in the ozone precursors are attributed to the GHG effect when using the described attribution method. The GHG effect is calculated as a combined effect from $\mathrm{CO}_{2}, \mathrm{CH}_{4}$ and $\mathrm{N}_{2} \mathrm{O}$ changes. The attribution to specifically $\mathrm{CO}_{2}, \mathrm{CH}_{4}$ or $\mathrm{N}_{2} \mathrm{O}$ changes is not possible. Thus, effects of interactions between the GHG-induced $\mathrm{HO}_{x}$ and $\mathrm{NO}_{x}$ changes, as reported for instance by Nevison et al. (1999), are not detectable.

To identify the processes causing nonlinear ozone changes, the annual mean ozone change is separated into the contributions from chemistry (chemical production and loss), transport and a residual term according to the method described in Garny et al. (2011b) and Meul et al. (2014). Since the polar regions exhibit a large seasonal variability in ozone chemistry and ozone transport, the analysis must be extended to seasonal data. This means that in the attribution method the tendency term is no longer small and has to be considered. A non-zero ozone tendency over one season means that ozone production, loss and transport are not balanced but cause a change in the local ozone abundance. Therefore, the contribution from the tendency term to the relative ozone change is interpreted as the difference in the seasonal imbalance between chemistry and transport between the climate states. In the following analysis, the tendency term is not shown, but it is considered (together with the residual term) when adding up the single contributions to the total.

To separate the chemical ozone loss into the different loss cycles, the tool StratO3Bud (for details see Meul et al., 2014) is applied to the model output. As discussed in Meul et al. (2014), a lower temporal resolution of the input data and a reduced set of reactions used in StratO3Bud lead, in some regions, to differences of the total ozone production and loss compared to the online integrated terms that are used for the separation into chemistry and transport. Therefore both loss quantities are shown in Sect. 3 for comparison.

The uncertainty of the nonlinear signals is calculated from the joint standard deviations, based on the concept of error propagation. Significant changes on the $95 / 99 \%$ confidence level are then estimated by the exceedance of $2 / 3$ times the standard deviation $(2 / 3 \sigma)$.

\section{Results}

\subsection{Ozone change and its drivers}

The annual mean, global mean ozone change between the years 1960 and 2000 is shown in Fig. 1a. Ozone mixing ratios are reduced throughout the stratosphere, with a maximum change of $-12 \%(=-3 \% /$ decade $)$ in the upper stratosphere (black line). This decrease is slightly smaller than that described in Jonsson et al. (2009) for the period 1975-1995. However, since the ozone decline was slower before 1975, the results are comparable. Consistent with the literature, the ozone decrease is mainly due to the increase in ODSs
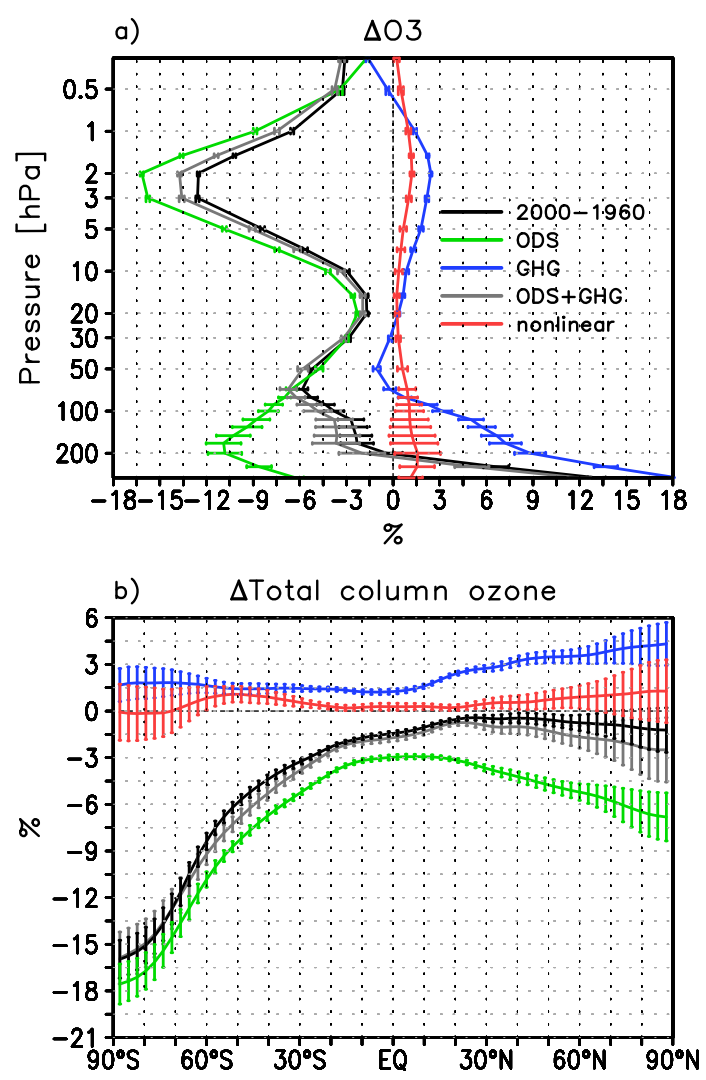

Figure 1. (a) Vertical profile of the annual mean global mean change in ozone mixing ratio (in percent) between 1960 and 2000 (black) and the contributions from GHGs (blue) and ODSs (green) and the nonlinear term (red). The sum of the single forcings $(\mathrm{GHG}+\mathrm{ODS})$ is shown in grey. The bars denote the $95 \%$ confidence level of the changes. (b) Same as (a) but for the latitude dependant annual mean change in total column ozone (in percent) between 1960 and 2000 .

(green). Rising levels of GHGs (blue) lead to an ozone increase in the middle and upper stratosphere (by up to $2.5 \%$ ) and hence counteract the ODS-induced ozone loss. The positive ozone change below $100 \mathrm{hPa}$ attributed to GHGs is probably caused by increasing concentrations of ozone precursors, but it is not distinguishable from the GHG effect due to our experimental setup (see Sect. 2). The GHG-induced ozone increase in the upper stratosphere is related to GHGinduced radiative cooling, which decelerates the temperature dependant ozone loss reactions (e.g. Rosenfield et al., 2002). The negative GHG-signal in the lower stratosphere, which is also found by Jonsson et al. (2009), originates from the tropics where a slightly strengthened upwelling reduces the local abundance of ozone (not shown). In the lower mesosphere, the overall ozone loss is enhanced by the GHG effect. This is caused by an increase of the $\mathrm{HO}_{x}$ mixing ratio, which is related to the higher $\mathrm{CH}_{4}$ emissions (e.g. Wuebbles and Hayhoe, 2002). A slightly negative ozone change attributed to 
$\mathrm{HO}_{x}$ in the lower mesosphere is also reported by Oman et al. (2010) for the period 1960 to 1999.

The annual mean change in the total ozone column between 1960 and 2000 is shown in Fig. 1b for all latitudes. Total column ozone decreases globally, with the largest changes $(-15 \%)$ occurring in the SH polar region. The pattern of the changes in the $\mathrm{SH}$ is qualitatively comparable to the trends derived from observations (Figs. 3-22 from WMO, 2007) for the period 1980-2004. In the tropics, however, the total ozone column change in the simulations is larger than in the observations. Furthermore, the meridional gradient of the $\mathrm{O}_{3}$ change in the Northern Hemisphere $(\mathrm{NH})$ in the observations is not captured by the model. Here, the different periods considered for the calculation may play a role. However, regarding the contribution from the ODSs, the ozone changes show this meridional gradient. This indicates that the change induced by the GHGs is too small in the tropics and too large in the NH, which suggests a slightly stronger increase in the transport of ozone from the tropics to the high latitudes in the time slice simulations compared to the observations.

\subsection{Nonlinear processes}

\subsubsection{Annual mean}

In the atmosphere, GHG and ODS abundances have increased simultaneously and nonlinear interactions can occur. The difference between the sum of the single forcings (grey) and the change of simultaneously increased GHG and ODS mixing ratios (black) is shown by the red line in Fig. 1. Throughout the stratosphere the nonlinear contribution to the annual mean global mean ozone change is positive (Fig. 1a). The largest nonlinear effect is found in the upper stratosphere, where it is as large as $1.2 \%$. Here, the ozone change due to nonlinearity is about half as large as the ozone change induced by GHG changes. Statistically significant nonlinear contributions are found above $100 \mathrm{hPa}$.

The vertically integrated nonlinear contribution for the different latitudes is shown in red in Fig. 1b. Significant positive changes are found in the extra-polar regions. At SH midlatitudes the nonlinear term causes up to $1.1 \%$ increase. Nonlinearity has a slightly negative (not significant) contribution in the SH polar region in the annual mean but a slightly positive contribution (not significant) in the $\mathrm{NH}$ polar region. All in all, due to nonlinear interactions between changing $\mathrm{GHG}$ and ODS concentrations, the resulting ozone loss in the recent past is slightly smaller than expected from the single forcings.

To analyse the processes that underlie the nonlinear ozone changes, the regions with significant nonlinear changes have to be identified. In Fig. 2a, showing the vertically and latitudinally resolved annual mean nonlinear ozone change, two stratospheric regions are found: the extra-polar upper stratosphere and the SH midlatitude lower stratosphere. Both regions exhibit positive nonlinear contributions to the overall ozone change of 1-2\%. These regions of statistically significant nonlinear changes are in relatively good agreement with the regions identified by Zubov et al. (2013) for the future.

In the following we investigate which processes exhibit nonlinear interactions in the different regions. For this purpose the annual mean nonlinear ozone change is separated into the contributions from chemical ozone loss, chemical ozone production and ozone transport, shown in Fig. $2 \mathrm{~b}-\mathrm{d}$ respectively. For the interpretation, it should be noted that not the changes in the processes are shown, but the changes in ozone that are attributed to the changed processes. Since the ozone tendency is inversely proportional to the (positive definite) chemical ozone loss, a positive ozone change attributed to chemical loss implies slowed ozone loss. It is found that in the upper stratosphere, the nonlinear ozone changes are caused by nonlinearities in the ozone chemistry, with a positive effect from ozone loss and a smaller negative from ozone production (Fig. 2b and c). In the tropical lower stratosphere and at NH midlatitudes the significant nonlinear effects from ozone loss and production nearly compensate each other, leading to insignificant changes in ozone. The positive nonlinear signal in the lower stratosphere at SH midlatitudes results from the contribution from both ozone chemistry and ozone transport. Nonlinear processes affecting the ozone transport cause an ozone increase in the tropical and $\mathrm{SH}$ midlatitudinal lower stratosphere and a decrease in the $\mathrm{SH}$ polar region (Fig. 2d). This indicates a reduced ozone transport into the $\mathrm{SH}$ polar stratosphere. However, to identify the involved processes it is necessary to analyse the seasonal changes in detail, since the BDC exhibits strong seasonal variability (see Sect. 3.2.2).

The next step is to understand how the nonlinear interactions are caused and which processes are responsible. First we analyse the reasons for the nonlinearity of the chemical ozone loss by separating the contributions from the different ozone loss cycles, applying the tool StratO3bud. For illustration, we show the attribution of the ozone changes due to ozone loss at $30^{\circ} \mathrm{N}$ and at $60^{\circ} \mathrm{S}$ (Fig. 3). Note that the use of StratO3bud can lead to quantitatively different results compared to Fig. 2b, which is indicated by the additional contour line (black with circles) in the top panel. In the upper stratosphere at NH midlatitudes (Fig. 3a), the nonlinear processes are acting in the same direction as the increasing GHG concentrations and are reducing the efficiency of the ozone loss, whereas the increase of the halogen loading causes an ozone decrease due to enhanced ozone loss. In the lower stratosphere both the GHG and ODS increase enhance the ozone loss. The nonlinear contribution, however, remains positive. At $60^{\circ} \mathrm{S}$ (Fig. 3b) the sign of the ozone changes attributed to increasing GHG and ODS concentrations is the same as at NH midlatitudes, but the ozone loss due to ODSs is clearly larger in the lower stratosphere, which is linked to the evolution of the ozone hole. The nonlinear contribution to the ozone change is very small and not significant between 50 and $10 \mathrm{hPa}$ and even slightly negative at $5 \mathrm{hPa}$, 

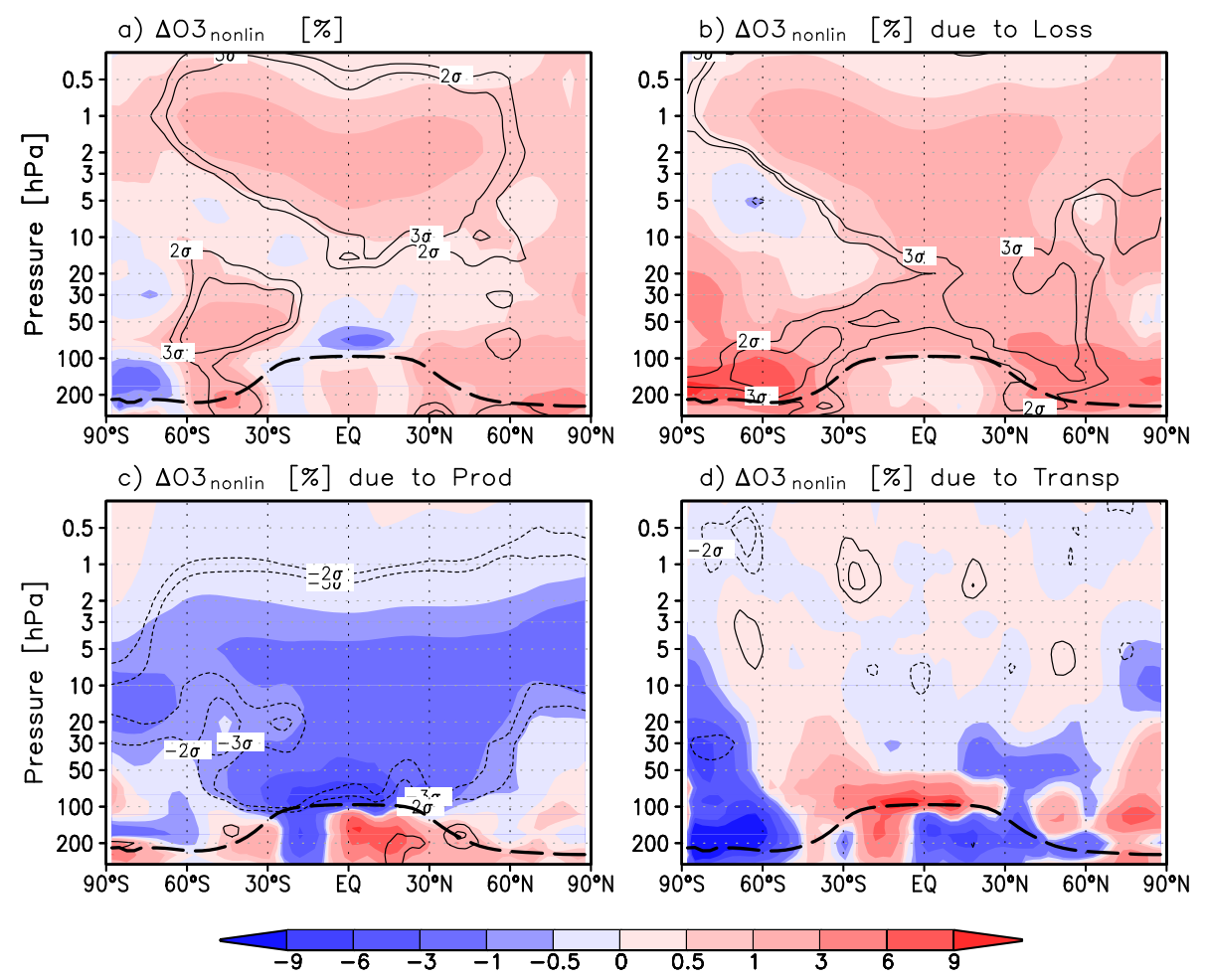

Figure 2. Latitude-height section of the nonlinear contribution to the annual mean ozone change (a) between 1960 and 2000 in percent and the separation into the contributions from ozone loss (b), ozone production (c) and ozone transport (d). Red/blue shading indicates positive/negative changes. The contour lines indicate the regions where the changes are larger than $\pm 2 \sigma$ and $\pm 3 \sigma$. The bold dashed line shows the mean tropopause location of the R1960 simulation for the annual mean. Note that the contributions from chemistry (b+c) and transport (d) do not exactly add up to the total (a) because of the residual term.

but in the lower stratosphere $8 \%$ of the overall annual mean ozone change is explained by nonlinear interactions.

By analysing the nonlinear contributions from different loss cycles (Fig. 3c and d), we find that at $\mathrm{NH}$ midlatitudes the nonlinear ozone increase is determined by a reduced ozone loss in the catalytic chlorine loss cycle (orange) above $70 \mathrm{hPa}$. In the upper stratosphere this increase is slightly counteracted by an enhanced ozone loss in the Chapman cycle (purple). In the middle stratosphere nonlinear interactions modify the $\mathrm{NO}_{x}$-catalysed $\mathrm{O}_{3}$ loss, while in the lower stratosphere the $\mathrm{HO}_{x}$ - and $\mathrm{BrO}_{x}$-catalysed $\mathrm{O}_{3}$ loss are affected. In contrast to the nonlinear effect on the $\mathrm{ClO}_{x}$ and Chapman cycles in the upper stratosphere, which varies only quantitatively but not qualitatively with latitude, the sign of the nonlinear ozone change due to the $\mathrm{NO}_{x}$ cycle depends on the geographical region. In the $\mathrm{NH}$ the nonlinear ozone change related to the $\mathrm{NO}_{x}$ cycle is relatively small and not statistically significant. In the $\mathrm{SH}$, however, ozone is significantly decreased by up to $2 \%$ in the upper stratosphere at midlatitudes (Fig. 3d) and increased in the middle stratosphere in the polar region due to a nonlinearly modified $\mathrm{NO}_{x}$-catalysed ozone loss (not shown). This causes the hemispheric asymmetries in the nonlinear ozone change attributed to chemical loss in Fig. 2b. In the lower stratosphere the nonlinear ozone change due to $\mathrm{HO}_{x}$ is positive at all latitudes, but statistically significant increases occur only at high latitudes. In the annual mean the total nonlinear decrease of the chemical $\mathrm{O}_{3}$ loss in the Antarctic lower stratosphere is caused by a reduced $\mathrm{HO}_{x}-, \mathrm{ClO}_{x^{-}}$and $\mathrm{BrO}_{x}$-catalysed $\mathrm{O}_{3}$ loss (Fig. 3d).

Which nonlinear processes are affecting the ozone loss cycles? Since the loss rate of a specific reaction is determined by the (temperature dependant) rate coefficient and the concentration of the involved species, nonlinear effects can occur either because of nonlinear temperature changes or/and nonlinear changes of the radical and ozone abundances. We find that the nonlinearity in the $\mathrm{ClO}_{x}$-induced ozone loss is primarily caused by a reduced concentration of $\mathrm{ClO}_{x}$ radicals if ODSs and GHGs are changed simultaneously, as compared to the sum of the single forcings (Fig. 4a). In the upper stratosphere the $\mathrm{ClO}_{x}$ increase between 1960 and 2000 is about $300 \%$, while the changes due to ODSs $(\approx+350 \%)$ and GHGs $(\approx-10 \%)$ add up to $\approx+340 \%$ (not shown). This is explained by a nonlinear effect on the partitioning of inorganic chlorine, consistent with the study by Nevison et al. (1999). From 1960 to 2000 the ratio between reactive $\left(\mathrm{ClO}_{x}\right)$ and inorganic chlorine is reduced more than expected from the single forcings. This is caused by the interaction between the chlorine species and the GHGs $\mathrm{CH}_{4}$ and $\mathrm{N}_{2} \mathrm{O}$. While $\mathrm{CO}_{2}$ 

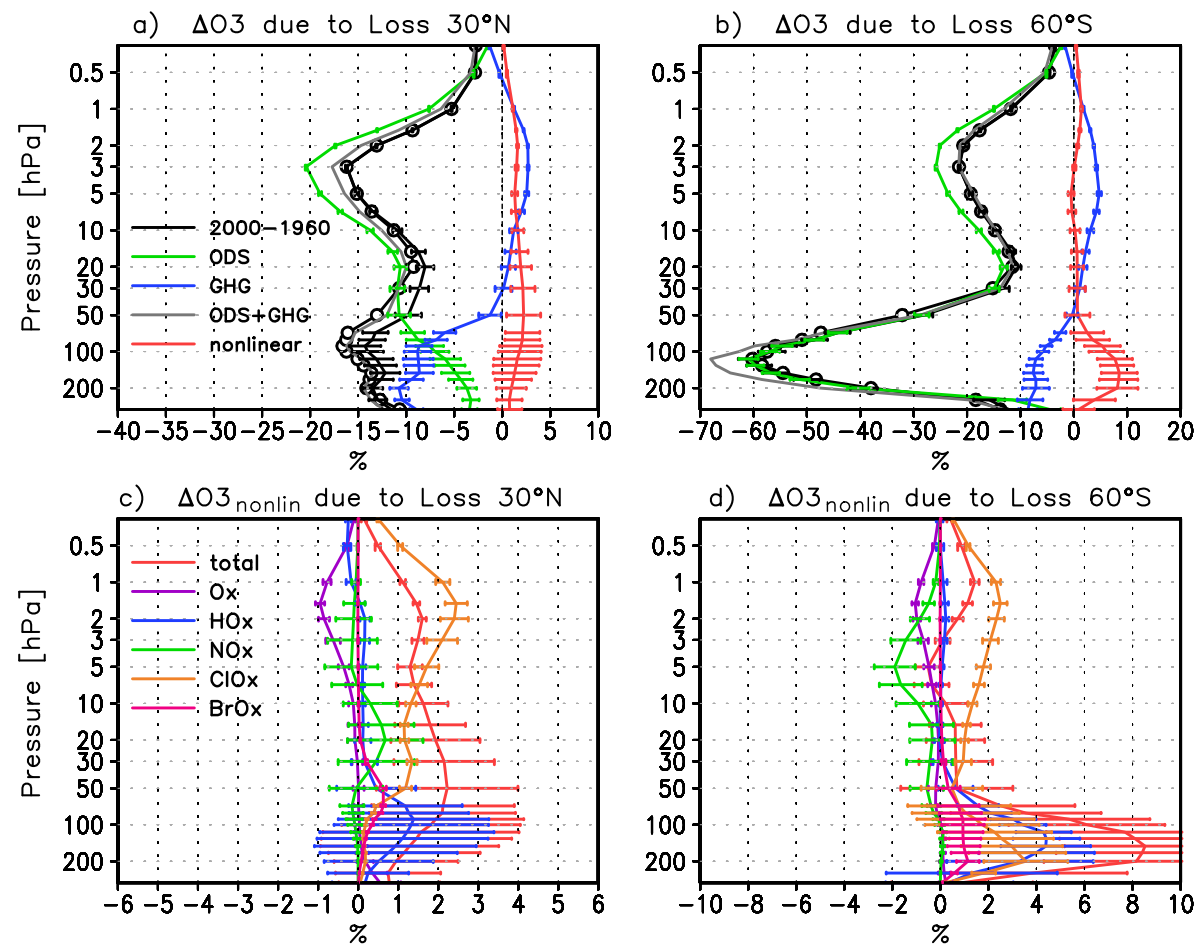

Figure 3. Top panels: vertical profile of the relative ozone change due to chemical ozone destruction (black) and its attribution to GHGs (blue), ODSs (green) and nonlinear interactions (red) for the annual mean at $30^{\circ} \mathrm{N}$ (a) and at $60^{\circ} \mathrm{S}(\mathbf{b})$. The results based on the calculation with the tool StratO3Bud are shown as solid lines. For comparison, the result of the total change calculated accordingly to Fig. $2 b$ is shown as black line with circles. Bottom: vertical profile of the nonlinear contribution to the loss-induced ozone change (red; see top panel) and the separation into the contributions from the different ozone loss cycles, i.e. the $\mathrm{O}_{x}$ (purple), $\mathrm{HO}_{x}\left(\right.$ blue), $\mathrm{NO}_{x}(\mathrm{green}), \mathrm{ClO}_{x}($ orange) and $\mathrm{BrO}_{x}$ (magenta) loss cycles for the annual mean at $30^{\circ} \mathrm{N}$ (c) and at $60^{\circ} \mathrm{S}$ (d). The bars denote the $95 \%$ confidence level of the changes. The contributions from the single loss cycles add up to the total loss change. Note the different scales of the subfigures.

a) $\Delta$ ClOx nonlin $\left[\times 10^{-11}\right]$ am
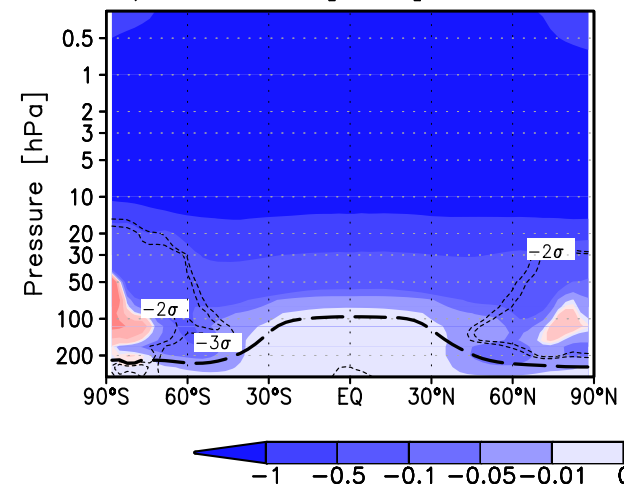

b) $\triangle \mathrm{NOX}$ nonlin $\left[\times 10^{-9}\right]$ SON

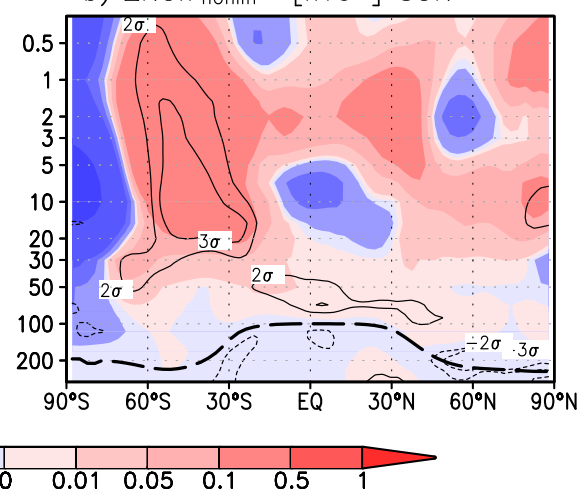

Figure 4. Latitude-height section of the nonlinear change of the annual mean $\mathrm{ClO}_{x}$ mixing ratio (a) and the September to November mean $\mathrm{NO}_{x}$ mixing ratio (b) between 1960 and 2000. The contour lines indicate the regions where the changes are larger than $\pm 2 \sigma$ and $\pm 3 \sigma$. The bold dashed line shows the mean tropopause location of the R1960 simulation for the annual mean and the SON mean respectively.

is chemically quasi-inert in the atmosphere and primarily influences the radiative budget of the system, $\mathrm{CH}_{4}$ and $\mathrm{NO}_{2}$ (a product species from $\mathrm{N}_{2} \mathrm{O}$ ) can react with chlorine compounds and form $\mathrm{HCl}$ and $\mathrm{ClONO}_{2}$ respectively, which are the most abundant chlorine reservoir species in the strato- sphere. Thus, the formation of chlorine reservoir species is enhanced if the GHG concentrations are increased simultaneously with the chlorine loading. This is also valid for the $\mathrm{BrO}_{x}$-catalysed $\mathrm{O}_{3}$ loss in the lower stratosphere through the formation of $\mathrm{BrONO}_{2}$. In addition, nonlinear processes lead 
to a reduced abundance not only of chlorine radicals but also of the total amount of inorganic chlorine in the stratosphere (not shown). This is related to a reduced conversion of the chlorine source gases to inorganic compounds in the tropical stratosphere. Here, the reduced short-wave radiation reaching the lower stratosphere due to the $\mathrm{O}_{3}$ increase above lowers the photolysis rate of organic chlorine. Furthermore, circulation changes can play a role for the chlorine release as discussed in Waugh et al. (2007).

The positive nonlinear effect on ozone shown here is contrary to the findings in Haigh and Pyle (1982), who found a larger ozone decrease for the combined change of ODSs and $\mathrm{CO}_{2}$. The main difference to the study by Haigh and Pyle (1982) is that not only $\mathrm{CO}_{2}$ concentrations but also the $\mathrm{CH}_{4}$ and $\mathrm{N}_{2} \mathrm{O}$ abundances are increased. This means that the nonlinear effect due to a reduced temperature sensitivity of ozone is smaller than the nonlinearity that originates from changing atmospheric abundances of $\mathrm{CH}_{4}$ and $\mathrm{N}_{2} \mathrm{O}$ and their interactions with chlorine species.

The rate limiting reaction of the Chapman loss cycle $\left(\mathrm{O}_{3}+\mathrm{O}\right)$ exhibits a strong temperature dependency resulting in reduced ozone loss if temperatures decrease and enhanced loss if temperatures increase. The annual mean nonlinear temperature change between 1960 and 2000 (Fig. 5) is positive and statistically significant in the tropical upper stratosphere and lower stratosphere at SH midlatitudes. Thus, the stratospheric cooling in the tropical upper stratosphere is weaker by up to $0.4 \mathrm{~K}$ if ODSs and GHGs are changed simultaneously, with the consequence that the ozone loss via the Chapman cycle is slightly increased. The temperature change pattern is linked to the nonlinear ozone increase due to the $\mathrm{ClO}_{x}$ cycle and the concomitant increase in ozone heating rates, but it is modulated by dynamical processes, especially in the polar regions. The warming in the SH polar upper stratosphere is related to a dynamically induced adiabatic descent that is probably caused by the cooling in the lower stratosphere. The cooling can partly be explained by reduced downwelling (see Sect. 3.2.2 and Fig. 8d).

The hemispheric asymmetry in the nonlinear ozone change in the lower and middle stratosphere is attributed to a larger nonlinear effect on the $\mathrm{NO}_{x}$ loss cycle in the $\mathrm{SH}$ that leads to a compensation of the $\mathrm{ClO}_{x}$-induced ozone increase at $\mathrm{SH}$ midlatitudes and to a larger nonlinear ozone increase in the polar region. This is mainly caused by processes in the SH spring season and will be discussed in Sect. 3.2.2.

The significant nonlinear annual mean ozone increase due to chemical loss in the lowermost stratosphere at SH high latitudes (Fig. 2b) is mainly caused by a reduced efficiency of $\mathrm{HO}_{x}$-catalysed $\mathrm{O}_{3}$ loss (see Fig. $3 \mathrm{~d}$ for $60^{\circ} \mathrm{S}$ ). At this altitude, the $\mathrm{HO}_{x}$ cycle is primarily determined by the reaction of $\mathrm{OH}$ with $\mathrm{O}_{3}$. Although the absolute abundance of $\mathrm{HO}_{x}$ is increased due to nonlinear processes, the partitioning between $\mathrm{OH}$ and $\mathrm{HO}_{2}$ is shifted in favour of $\mathrm{HO}_{2}$ in this region (not shown). Thus, the loss efficiency is reduced.

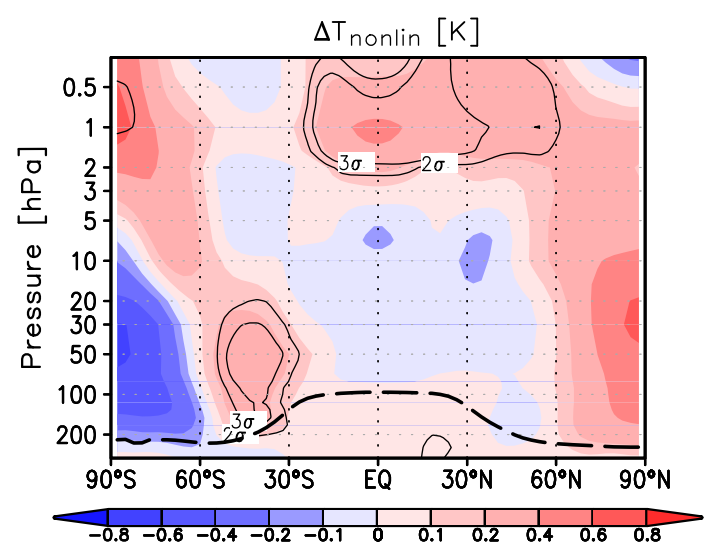

Figure 5. Same as Fig. 2a but for the nonlinear annual mean temperature change (K) between 1960 and 2000. The contour lines indicate the regions where the changes are larger than $\pm 2 \sigma$ and $\pm 3 \sigma$.

In addition to chemical ozone loss, chemical ozone production contributes to the nonlinear ozone signal. Figure $2 \mathrm{c}$ shows that ozone production is reduced if interactions between increasing GHGs and ODSs occur. It is mainly caused by a decrease of the photolysis rate due to the ozone increase in the levels above (i.e. a reversed self-healing effect). The nonlinear ozone increase attributed to production changes in the NH upper troposphere, however, is found to be due to increased production via the reaction path $\mathrm{HO}_{2}+\mathrm{NO}$ (not shown).

The processes that are responsible for the nonlinear change in the ozone transport are analysed in more detail from the seasonal point of view in the next section. To investigate the seasonality of the nonlinear ozone changes, the attribution method is applied to seasonal means as discussed in Sect. 2. The largest nonlinear contributions are found in the September to November (SON) season. Therefore we focus on the SON mean in the following analyses.

\subsubsection{Southern Hemisphere spring (SON)}

Figure 6 shows the nonlinear ozone change between 1960 and 2000 for the SH spring season (SON) and the attributions to chemical ozone loss, production and transport analogous to Fig. 2. Figure 6a shows that the nonlinear ozone increase in the extra-polar upper stratosphere that was found for the annual mean is a robust signal in austral spring (and in fact all seasons; not shown). In the lower stratosphere, however, the nonlinear ozone change in the SON mean exhibits a clear dipole pattern in the $\mathrm{SH}$, with a positive signal at midlatitudes and a negative signal in the polar region. Furthermore, a statistically significant ozone increase due to nonlinear interactions is found in the $\mathrm{NH}$ polar lower stratosphere.

The nonlinear ozone changes due to loss in the SON mean (Fig. 6b) are qualitatively similar to the annual mean, but in the $\mathrm{SH}$ polar region the changes are more pronounced. The nonlinear contribution is positive in the upper and lower 

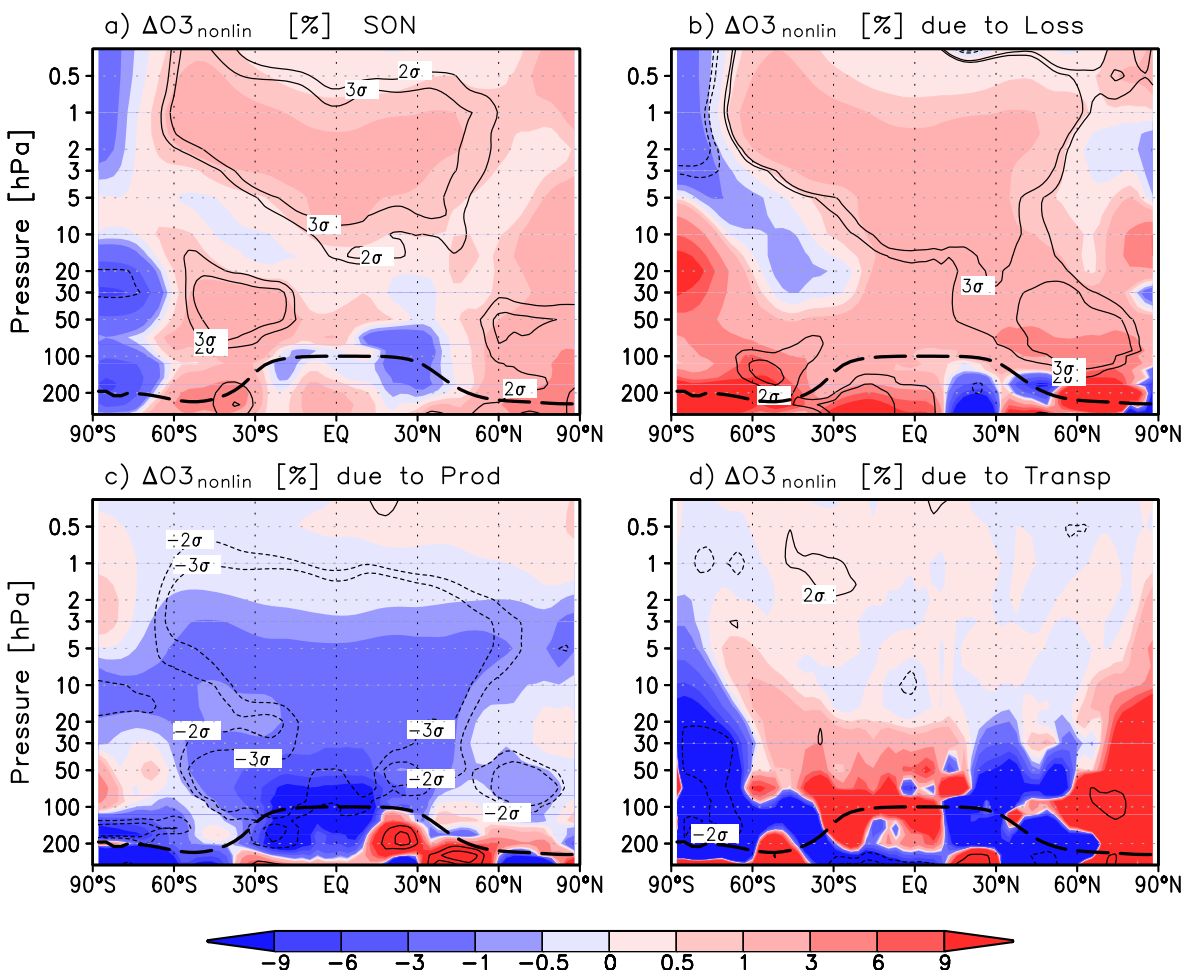

Figure 6. Same as Fig. 2 but for the SON (September-October-November) mean. See text for details.

a) $\Delta 03_{\text {nonlin }}^{[\%]}$ due to $\mathrm{ClOx}$ SON

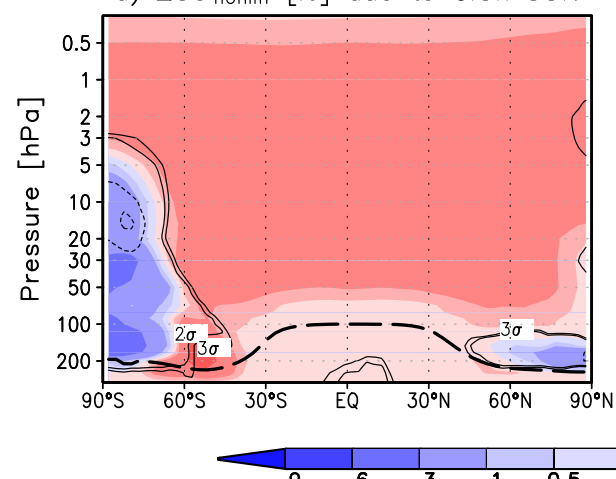

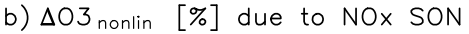

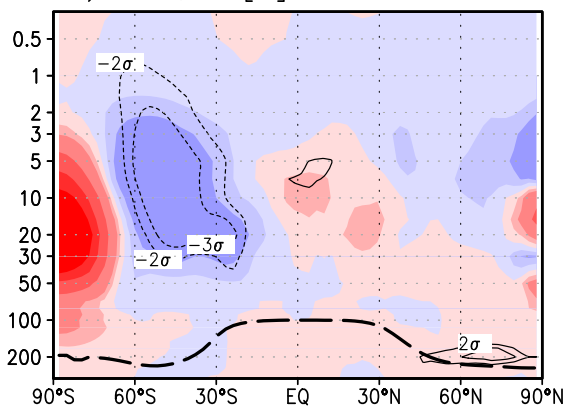

Figure 7. Latitude-height section of the $\mathrm{SON}$ mean nonlinear $\mathrm{O}_{3}$ changes due to the $\mathrm{ClO}_{x}$ (a) and the $\mathrm{NO}_{x}$ cycle (b) derived from StratO3Bud.

extra-polar stratosphere, as in the annual mean, but an ozone decrease is attributed to nonlinear processes at SH midlatitudes in the middle stratosphere and in the polar region in the upper stratosphere and lower mesosphere. This decrease is caused by significantly enhanced ozone loss through the $\mathrm{NO}_{x}$ cycle - by more than $2 \%$ (Fig 7b) - which slightly exceeds the ozone increase due to reduced $\mathrm{ClO}_{x}$-catalysed $\mathrm{O}_{3}$ loss (Fig. 7a; see Sect. 3.2.1 for more details to the $\mathrm{ClO}_{x}$ catalysed $\mathrm{O}_{3}$ loss change). In the $\mathrm{SH}$ polar region, however, the nonlinear $\mathrm{NO}_{x}$-catalysed $\mathrm{O}_{3}$ loss is decreased and thus ozone is increased in the middle stratosphere between 50 and
$5 \mathrm{hPa}$ (Fig. 7b). In the NH, no comparable nonlinear change pattern is found in the spring season (March to May; not shown).

The nonlinearity in $\mathrm{NO}_{x}$-catalysed $\mathrm{O}_{3}$ loss originates from a nonlinear change of the $\mathrm{NO}_{x}$ mixing ratios in the atmosphere: it is positive at $\mathrm{SH}$ midlatitudes and negative in the polar region (Fig. 4b). To understand this nonlinear behaviour, we first explain the effect of the single forcings, since the $\mathrm{NO}_{x}$ mixing ratios are affected by both increasing GHGs and ODSs. In the stratosphere $\mathrm{N}_{2} \mathrm{O}$ is destroyed either by photolysis or by the reaction with an excited oxygen 
atom $\mathrm{O}^{1} \mathrm{D}$. However, only the latter reaction path produces $\mathrm{NO}_{x}$. Increasing halogen loading leads to a reduction of stratospheric $\mathrm{NO}_{x}$ above the $50 \mathrm{hPa}$ level by diminishing the overhead ozone column and thus increasing the photolysis rate of $\mathrm{N}_{2} \mathrm{O}$, which mitigates the $\mathrm{NO}_{x}$ production. Furthermore, an enhanced formation of reservoir species $\left(\mathrm{ClONO}_{2}\right.$, $\mathrm{BrONO}_{2}$ ) may also contribute to the $\mathrm{NO}_{x}$ reduction (not shown). In contrast, increasing GHG concentrations cause a significantly larger abundance of nitrogen radicals in the extra-polar stratosphere (not shown) which is linked to increased $\mathrm{N}_{2} \mathrm{O}$ input into the stratosphere. In the upper stratosphere and mesosphere, GHG-induced stratospheric cooling increases the $\mathrm{NO}_{y}$ loss reaction rate (Rosenfield and Douglass, 1998) and therefore causes a $\mathrm{NO}_{x}$ decrease. The combined $\mathrm{NO}_{x}$ change is dominated by the positive GHG effect in the tropical middle stratosphere and by the negative ODS effect in the polar regions and lower stratosphere. In the upper stratosphere and lower mesosphere the total $\mathrm{NO}_{x}$ change between 1960 and 2000 is negative.

This means that in the $\mathrm{SH}$, the combined change of ODSs and GHGs leads to a larger $\mathrm{NO}_{x}$ decrease in the polar region than expected from the sum of the single forcings (shown in Fig. 4b). At midlatitudes, the $\mathrm{NO}_{x}$ decrease is mitigated by nonlinear processes. Since this pattern dominates also the annual mean change (not shown), seasonally asymmetric processes must be involved. In the lower stratosphere the distribution of $\mathrm{NO}_{x}$ is determined by the release from reservoir species which are produced from $\mathrm{N}_{2} \mathrm{O}$ and transported via the residual circulation. Thus, nonlinear $\mathrm{NO}_{x}$ changes in the lower stratosphere can be caused by changes in the $\mathrm{NO}_{y}$ production, in the circulation and/or in the $\mathrm{NO}_{x} / \mathrm{NO}_{y}$ ratio. In the upper stratosphere the dominant form of odd nitrogen is $\mathrm{NO}_{x}$. Due to the chemical loss through the reaction $\mathrm{NO}+\mathrm{N}$ in the upper stratosphere and mesosphere, a maximum mixing ratio of $\mathrm{NO}_{x}$ occurs at $3 \mathrm{hPa}$. Thus, air masses that are transported downward from the mesosphere are characterized by lower $\mathrm{NO}_{x}$ values.

In the lower stratosphere we find qualitatively the same nonlinear change pattern for $\mathrm{NO}_{y}$ as for $\mathrm{NO}_{x}$, with only slightly masked absolute values due to a modified partitioning of radicals and reservoir species. Since the release from $\mathrm{N}_{2} \mathrm{O}$ shows no significant nonlinear change in the tropics (not shown), a possible explanation for the nonlinear $\mathrm{NO}_{y}$ change is an effect of transport. In the upper stratosphere the larger ozone abundance due to nonlinear processes can reduce the photolysis of $\mathrm{NO}$ which reduces the efficiency of the $\mathrm{NO}_{x}$ loss reaction (Rosenfield and Douglass, 1998). Furthermore, the reduced cooling in the tropical upper stratosphere (Fig. 5) tends to decrease the loss. This leads to an increase of $\mathrm{NO}_{x}$. However, the dipole pattern cannot be explained by these processes. Therefore, transport changes must be involved. The circulation changes due to nonlinear processes are discussed later in more detail.

The significant ozone decrease attributed to chemical loss in the SH polar upper stratosphere in the SON mean (Fig. 6b) is caused by increased $\mathrm{O}_{3}$ loss in the Chapman and the $\mathrm{HO}_{x}$ cycle, which together exceed the effect of the $\mathrm{ClO}_{x}$ decrease (not shown). The enhanced $\mathrm{O}_{3}$ loss in the Chapman cycle is explained by nonlinear warming (see Fig. 5 , because the SON nonlinear temperature change is comparable to the annual mean), while the increased $\mathrm{O}_{3}$ loss due to $\mathrm{HO}_{x}$ is related to a nonlinear increase of the $\mathrm{HO}_{x}$ mixing ratio in the upper stratosphere (not shown).

While the $\mathrm{ClO}_{x}$-catalysed $\mathrm{O}_{3}$ loss is significantly reduced at all latitudes and all seasons in the upper stratosphere due to nonlinear processes, a significant nonlinear ozone decrease occurs in the $\mathrm{SH}$ polar region between 20 and $5 \mathrm{hPa}$ in the SON mean (Fig. 7a). This is not explained by a nonlinear change of the $\mathrm{ClO}_{x}$ mixing ratio but is probably related to the reduced ozone loss in the $\mathrm{NO}_{x}$ cycle that leads to more $\mathrm{O}_{x}$ available for the catalytic $\mathrm{ClO}_{x}$ cycle. However, the overall nonlinear ozone change attributed to loss in this region is dominated by the ozone increase due to $\mathrm{NO}_{x}$.

The nonlinear ozone change attributed to chemical production (Fig. 6c) depends on the seasonality of the incoming solar radiation and is therefore slightly different from the annual mean. The contribution to the nonlinear ozone change, however, remains negative.

All in all, we find that ozone chemistry is affected by nonlinear changes, but it cannot fully explain the nonlinear ozone changes, in particular the ozone decrease in the Antarctic lower stratosphere in spring. Figure $6 \mathrm{~d}$ shows the nonlinear ozone change due to ozone transport in the Antarctic spring season. The pattern is qualitatively similar to that for the annual mean (Fig. 2d), which indicates that the effect of nonlinear interactions on ozone transport is largest in the SH spring season. We find a strong dipole signal in each hemisphere: in the SH a significant decrease in ozone due to transport in the polar stratosphere and an increase in the tropics and midlatitudes, and vice versa in the NH. Hence, the nonlinear ozone change pattern in the $\mathrm{SH}$ is primarily determined by the nonlinear changes in the ozone transport.

To understand why this dynamically driven nonlinearity is generated, we analyse the changes in the residual mean mass stream function $(\Psi)$. Figure 8a shows the change in the mass stream function between 1960 and 2000 for the SON mean. The contributions from GHGs, ODSs and the nonlinear term are illustrated in Fig. 8b-d respectively. The absolute field of the stream function is positive for clockwise transport from the equator to the north pole. The zero $\Psi$ line of the 1960 reference simulation is shown in green.

The residual mean circulation is strengthened throughout the stratosphere in the NH between 1960 and 2000 in the SON mean. In the SH the circulation is enhanced in the upper stratosphere and weakened in the lower stratosphere. This is consistent with the results by $\mathrm{Li}$ et al. (2008), who analysed simulations with a CCM and reported a weakening of the downward motion in the Antarctic lower stratosphere in SON for the 1960 to 2004 period and an enhancement of the downwelling in the upper stratosphere. 

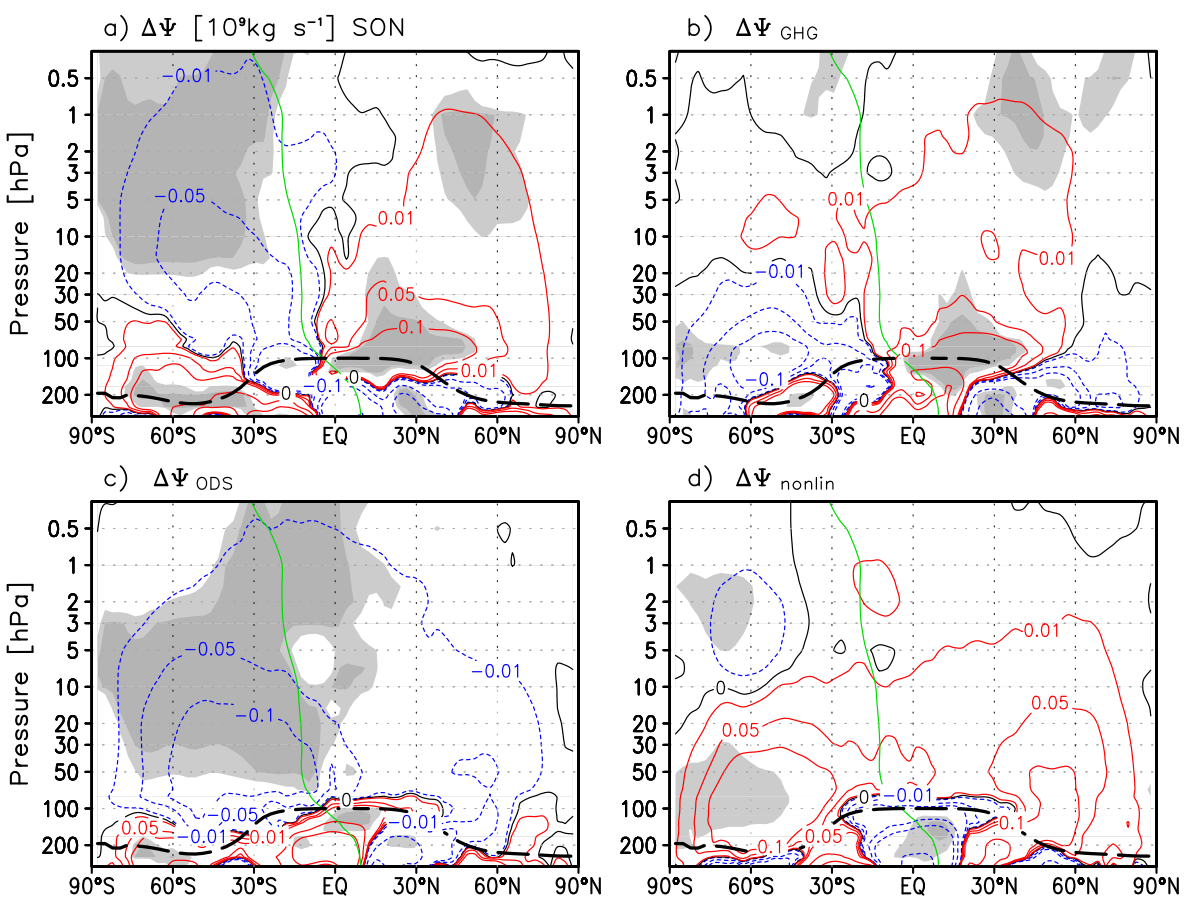

Figure 8. Latitude-height section of the changes in the residual mean mass stream function $(\Psi)$ in $10^{9} \mathrm{~kg} \mathrm{~s}^{-1}$ between 1960 and 2000 for the SON mean (a) and the changes due to GHGs (b) and ODSs (c) as well as the nonlinear contribution (d). The light/dark grey shading indicates statistically significant changes on the $95 / 99 \%$ confidence level respectively. The green contour line shows the zero line of the absolute residual mean mass stream function of the 1960 reference simulation (R1960).

The change in the $\mathrm{SH}$ and $\mathrm{NH}$ upper stratosphere in the EMAC simulations can be explained by the GHG and ODS forcings respectively (Fig. $8 \mathrm{~b}$ and c) but the weakening in the SH lower stratosphere occurs only if ODSs and GHGs are changed simultaneously. This result shows that in contrast to the findings by McLandress et al. (2010), we detect a small, but significant nonlinear response in our time slice simulations. This is potentially related to the different approach (time slice vs. transient simulations) used in our study compared to McLandress et al. (2010) and also to the fact that the chemical effect of increasing $\mathrm{CH}_{4}$ and $\mathrm{N}_{2} \mathrm{O}$ is solely included in our "GHG only" and not in our "ODS only" simulation as it is in the study by McLandress et al. (2010). Thus in our study, nonlinear effects on the dynamics arising from nonlinear ozone changes are more likely to be detected.

Due to increasing GHG concentrations, the residual circulation is enhanced in the $\mathrm{NH}$ upper stratosphere and in the lower stratosphere at low latitudes as well as in the SH lower stratosphere (Fig. 8b). A reduced wave dissipation in the upper troposphere (seen in the reduced Eliassen-Palm flux (EPF) convergence; Fig. S1b in the Supplement) leads to enhanced wave propagation into the lower stratosphere at midlatitudes in both hemispheres. In the SH the wave dissipation is enhanced between 100 and $10 \mathrm{hPa}$, leading to a strengthening of the circulation, particularly in the lower stratosphere; however, for the $\mathrm{NH}$ midlatitudes, the atmospheric structure favours wave propagation (indicated by the change in the re- fractive properties ( $\mathrm{Li}$ et al., 2007); see Fig. S2b) into the upper stratosphere, where the waves dissipate and drive the change of the mean mass stream function in the upper part (Figs. S1b and 8b).

In contrast, ODS increase leads to an enhancement of the mass transport in the $\mathrm{SH}$ and a reduction in the $\mathrm{NH}$ (Fig. 8c), which is also reported by Rind et al. (2009). In the SH the source region of wave energy (EPF divergence) in the upper troposphere/lower stratosphere (UTLS) between 30 and $60^{\circ} \mathrm{S}$ is shifted poleward and intensified (see Fig. S1c). This is probably related to a slight poleward shift of the SH subtropical jet, which is caused by the cooling trend in the Antarctic lower stratosphere and an increase of the latitudinal temperature gradient. The shift of the $\mathrm{SH}$ subtropical jet is a known feature in summer months (e.g. Wilcox et al., 2012), but it already starts to develop in SON in the time slice simulations. In addition, wave dissipation is reduced in the lower stratosphere at midlatitudes, i.e. the atmosphere is more permeable, which leads to increased EPF convergence in the middle and upper SH stratosphere (see Figs. S2c and S1c respectively) and to a strengthening of the $\mathrm{SH}$ residual circulation (Fig. 8c). The improved conditions for wave propagation are linked to the positive change of the zonal mean zonal wind (see Fig. S3c), which accompanies a later breakdown of the polar vortex (not shown). The NH weakening is explained by Rind et al. (2009), with an extension of the SH circulation 
change into the $\mathrm{NH}$ leading to reduced downwelling at high $\mathrm{NH}$ latitudes.

Finally, nonlinear changes occur, for example, if changes in the atmospheric conditions due to ODSs favour or mitigate the propagation of waves, which in turn are caused by increasing GHGs. In our simulations we find that the strengthening of the residual circulation in the SH lower stratosphere, which arises from both GHG and ODS changes, is weaker for the combined forcing (Fig. 8d). Here, different processes play a role. On the one hand, the wave activity from below is decreased due to less reduced (= increased) wave dissipation in the troposphere. This is linked to a weaker increase of the zonal wind around $60^{\circ} \mathrm{S}$ (see Figs. S1 and S3), which is associated with a weaker meridional temperature gradient in the UTLS and a reduced poleward shift of the SH subtropical jet (compared to the sum of the single forcings). This shift also induces a weakening of the EPF divergence in the lowermost stratosphere (see Figs. S1d and S3d). On the other hand, the middle stratosphere is more permeable for waves (see Figs. S1d and S2d), which is related to the greater persistence of the polar vortex in SH spring for the combined forcings compared to the sum of the single forcings (not shown), meaning a longer period of westerly winds in spring (see Fig. S3d). Thus, while wave dissipation is reduced in the middle stratosphere, it is enhanced in the upper stratosphere, driving the positive circulation change there (Fig. 8d).

In the NH the weakening of the residual circulation caused by ODSs and, in the polar lower stratosphere, by GHGs is compensated by nonlinear interactions. The wave dissipation in the troposphere is decreased at midlatitudes, allowing more waves to propagate into the stratosphere. As a consequence the wave dissipation in the middle and upper stratosphere is increased, driving the positive change of the residual circulation (Figs. S1d and 8).

This nonlinear behaviour of the mass stream function is consistent with the changes of the ozone transport, since reduced transport from the tropics to the polar regions causes ozone increase at midlatitudes and decrease at high latitudes. At the same time, a strengthening of the mass stream function in the NH lower stratosphere occurs, which causes an increased transport of ozone to the higher latitudes. Moreover, the changes of the residual circulation provide a possible explanation for the nonlinear $\mathrm{NO}_{x}$ change pattern in the lower stratosphere (Fig. 4b). A slower mass transport from the tropics to the mid- and high latitudes goes along with a longer transport time, which means that more time is available for the chemical conversion of $\mathrm{N}_{2} \mathrm{O}$. The reduced $\mathrm{NO}_{x}$ values south of $70^{\circ} \mathrm{S}$ are probably linked to the transport barrier at the edge of the polar vortex, which is more persistent when ODSs and GHGs are increased simultaneously (not shown). In the upper stratosphere, the increased downward motion transports air with low $\mathrm{NO}_{x}$ to the polar region and explains the $\mathrm{NO}_{x}$ decrease.

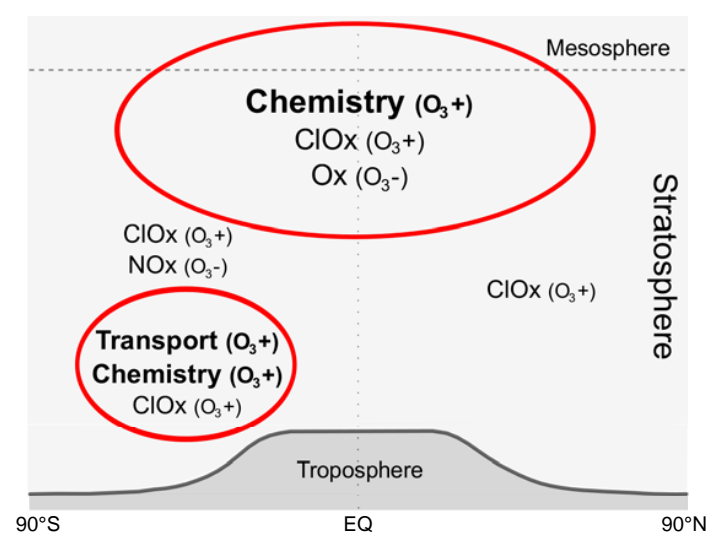

Figure 9. Schematic figure of the annual mean nonlinear ozone change between 1960 and 2000 and the main processes we have identified. $\left(\mathrm{O}_{3}+\right) /\left(\mathrm{O}_{3}-\right)$ means positive/negative change of ozone due to the indicated process.

\section{Conclusions}

In this study we have performed an attribution of ozone changes between 1960 and 2000 to increasing GHGs and ODSs, explicitly accounting for nonlinearities. A set of idealised simulations with the CCM EMAC allows us to detect nonlinear contributions to changes and to analyse the underlying processes. In contrast to attribution studies using the stratospheric halogen loading as explanatory variable, this method includes all preceding processes like transport and chemical conversion of the halogen source gases. GHGinduced changes in the processing of ODSs and the resulting ozone changes are therefore attributed not to ODS changes but to the nonlinear interaction term. Furthermore, by attributing the ozone changes to increasing mixing ratios of well-mixed GHGs, both temperature and chemical modifications are considered as opposed to only temperature or $\mathrm{CO}_{2}$ changes. Thus, ODS-induced changes in the abundance of $\mathrm{HO}_{x}$ and $\mathrm{NO}_{x}$ and the resulting ozone changes are attributed to nonlinear processes.

We identified a positive nonlinear contribution to the annual mean global mean ozone change throughout the stratosphere. The largest nonlinear change of $1.2 \%$ occurs in the upper stratosphere, where it is half as large as the GHGinduced ozone change. This signal is robust in the extrapolar region in all seasons. The main processes that we found driving the nonlinear ozone changes are summarised in the schematic overview in Fig. 9. In the extra-polar upper stratosphere, the nonlinear ozone increase is mainly attributed to nonlinearities in chemical ozone loss. We showed that reduced ozone loss is mainly caused by nonlinear processes affecting the $\mathrm{ClO}_{x}$ loss cycle. Interactions between the chlorine species and $\mathrm{CH}_{4}$ or $\mathrm{N}_{2} \mathrm{O}$ products lead to an enhanced formation of chlorine reservoir species, which decrease chemical ozone loss and increase ozone abundance by up to $2.5 \%$. This is consistent with the results of Nevison et al. (1999). 
The $\mathrm{ClO}_{x}$ effect is counteracted by more effective ozone loss via the Chapman cycle, which means that the temperatureinduced decrease of the Chapman loss reaction rate is smaller if GHGs and ODSs were changed at the same time. This is consistent with the findings of Haigh and Pyle (1982), who showed that the sensitivity of ozone to temperature changes decreases with increasing chlorine loading. In the middle stratosphere, nonlinear ozone change due to the $\mathrm{NO}_{x}$ cycle is slightly positive at $\mathrm{NH}$ midlatitudes but larger and negative at SH midlatitudes, which leads to hemispheric asymmetries in the nonlinear ozone loss signal.

Besides the significant nonlinear ozone change in the extra-tropical upper stratosphere, a second region with significant nonlinear annual mean changes is identified in the lower stratosphere SH midlatitudes. Here, reduced $\mathrm{ClO}_{x}$ catalysed ozone loss together with positive changes in ozone transport are found to be the main drivers of a nonlinear ozone increase. A nonlinear contribution is also found in ozone production, which is significantly reduced globally except for the lower polar stratosphere. The reduced production is related to a reduced photolysis rate of molecular oxygen, which is the consequence of the ozone increase above.

In the $\mathrm{SH}$ in spring (SON), a pronounced dipole pattern in the nonlinear ozone change is evident below $10 \mathrm{hPa}$, with ozone decrease in the polar region and increase at midlatitudes. This is mainly attributed to nonlinear processes affecting ozone transport but also modulated by nonlinear changes in the ozone chemistry. Due to a nonlinearly weakened meridional mass transport from the tropics and midlatitudes to the SH polar region, less ozone is transported to the high latitudes in the lower stratosphere. In the $\mathrm{NH}$, however, nonlinear interactions lead to an enhanced mass transport and hence to a positive ozone change attributed to transport in the high latitudes and a negative ozone change at midlatitudes. Here, the reduced ozone loss in the $\mathrm{ClO}_{x}$ cycle balances the negative signal at midlatitudes and enhances the positive signal at high latitudes. In contrast, at $\mathrm{SH}$ midlatitudes the nonlinearly enhanced ozone loss in the $\mathrm{NO}_{x}$ cycle exceeds the positive signal from the $\mathrm{ClO}_{x}$ cycle in the middle stratosphere. No enhancement of the heterogeneous ozone loss due to nonlinear processes is detected in the ozone hole area in spring; instead, there is a (not significant) mitigation of the chemical ozone depletion.

The integrated effect of the nonlinear processes is evident in the change of the total ozone column. The ODS-induced decrease is significantly mitigated in the extra-polar regions by up to $1.1 \%$ in the annual mean.

All in all, we showed that in simulations with the CCM EMAC, simultaneously increased GHG and ODS concentrations lead to nonlinear interactions affecting both ozone chemistry and ozone transport between 1960 and 2000. The nonlinear effect on ozone is small compared to the ODS effect, but for the recent past it is about half as large as the GHG effect. It has to be noted that these results are based on a single model study. Douglass et al. (2012) showed that dif- ferences in the balance of loss processes between different CCMs lead to different sensitivity of ozone to temperature and chlorine changes in the upper stratosphere. Analyses of the nonlinear processes with different models are thus needed to confirm the conclusions shown here.

For attribution studies with multiple linear regression analysis, however, one has to be aware of the fact that the basis functions may already be modified by nonlinear interactions. Therefore some processes are not included in the attribution. The appearance of nonlinearities means that the effect of ODS emission changes is to a small percentage dependant on the prevailing GHG concentrations. Thus the future evolution of stratospheric ozone due to the decline of ODSs will not simply be a reversal of the past.

\section{The Supplement related to this article is available online at doi:10.5194/acp-15-6897-2015-supplement.}

Acknowledgements. This work has been funded by the Deutsche Forschungsgemeinschaft (DFG) within the research unit SHARP (LA 1025/14-2 and LA 1025/13-2) and within the project ISOLAA (LA 1025/19-1). We thank Blanca Ayarzagüena for many helpful discussions and Edwin Gerber for proofreading. Furthermore, we would like to thank the North-German Supercomputing Alliance (HLRN) for computing time and support.

Edited by: F. Khosrawi

\section{References}

Austin, J., Struthers, H., Scinocca, J., Plummer, D. A., Akiyoshi, H., Baumgaertner, A. J. G., Bekki, S., Bodeker, G. E., Braesicke, P., Brühl, C., Butchart, N., Chipperfield, M. P., Cugnet, D., Dameris, M., Dhomse, S., Frith, S., Garny, H., Gettelman, A., Hardiman, S. C., Joeckel, P., Kinnison, D., Kubin, A., Lamarque, J. F., Langematz, U., Mancini, E., Marchand, M., Michou, M., Morgenstern, O., Nakamura, T., Nielsen, J. E., Pitari, G., Pyle, J., Rozanov, E., Shepherd, T. G., Shibata, K., Smale, D., Teyssèdre, H. and Yamashita, Y.: Chemistry-climate model simulations of spring Antarctic ozone, J. Geophys. Res., 115, D00M11, doi:10.1029/2009JD013577, 2010b.

Butchart, N. and Scaife, A.: Removal of chlorofluorocarbons by increased mass exchange between the stratosphere and the troposphere in a changing climate, Nature, 410, 799-802, 2001.

Cicerone, R. J., Walters, S., and Liu, S. C.: Nonlinear response of stratospheric ozone column to chlorine injections, J. Geophys. Res., 88, 3647-3661, doi:10.1029/JC088iC06p03647, 1983.

Cook, P. A. and Roscoe, H. K.: Changes in reactive stratospheric gases due to a change in Brewer-Dobson circulation: results from a simple model, Atmos. Sci. Lett., 13, 49-54, doi:10.1002/asl.362, 2012.

Douglass, A. R., Stolarski, R. S., Strahan, S. E., and Oman, L. D.: Understanding differences in upper stratospheric ozone response to changes in chlorine and temperature as computed 
using CCMVal-2 models, J. Geophys. Res., 117, D16306, doi:10.1029/2012JD017483, 2012.

Eyring, V., Cionni, I., Bodeker, G. E., Charlton-Perez, A. J., Kinnison, D. E., Scinocca, J. F., Waugh, D. W., Akiyoshi, H., Bekki, S., Chipperfield, M. P., Dameris, M., Dhomse, S.,Frith, S. M., Garny, H., Gettelman, A., Kubin, A., Langematz, U., Mancini, E., Marchand, M., Nakamura, T., Oman, L. D., Pawson, S., Pitari, G., Plummer, D. A., Rozanov, E., Shepherd, T. G., Shibata, K., Tian, W., Braesicke, P., Hardiman, S. C., Lamarque, J. F., Morgenstern, O., Pyle, J. A., Smale, D., and Yamashita, Y.: Multimodel assessment of stratospheric ozone return dates and ozone recovery in CCMVal-2 models, Atmos. Chem. Phys., 10, 94519472, doi:10.5194/acp-10-9451-2010, 2010.

Fioletov, V. E., Bodeker, G. E., Miller, A. J., McPeters, R. D., and Stolarski, R.: Global and zonal total ozone variations estimated from ground-based and satellite measurements: 1964-2000, J. Geophys. Res.-Atmos., 107, 4647, doi:10.1029/2001JD001350, 2002.

Garny, H., Dameris, M., Randel, W., Bodeker, G. E., and Deckert, R.: Dynamically Forced Increase of Tropical Upwelling in the Lower Stratosphere, J. Atmos. Sci., 68, 1214-1233, doi:10.1175/2011JAS3701.1, 2011a.

Garny, H., Grewe, V., Dameris, M., Bodeker, G. E., and Stenke, A.: Attribution of ozone changes to dynamical and chemical processes in CCMs and CTMs, Geosci. Model Dev., 4, 271-286, doi:10.5194/gmd-4-271-2011, $2011 \mathrm{~b}$.

Haigh, J. D. and Pyle, J. A.: Ozone perturbation experiments in a two-dimensional circulation model, Q. J. Roy. Meteorol. Soc., 109, 551-574, doi:10.1002/qj.49710845705, 1982.

IPCC - Intergovernmental Panel on Climate Change: Climate Change 1995: The Science of Climate Change, in: Contribution of Working Group I to the Second Assessment Report of the Intergovernmental Panel on Climate Change, edited by: Houghton, J. T., Meira Filho, L. G., Callander, B. A., Harris, N., Kattenberg, A., and Maskell, K., Cambridge University Press, Cambridge, UK and New York, USA, 1996.

IPCC - Intergovernmental Panel on Climate Change: Climate change 2001: The Scientific Basis, in: Contribution of Working Group I to the Third Assessment Report, edited by: Houghton, J. T., Ding, Y., Griggs, D. J., Noguer, M., van der Linden, P. J., Dai, X., Maskell, K., and Johnson, C. A., Cambridge University Press, Cambridge, UK and New York, NY, USA, 2001.

Jöckel, P., Tost, H., Pozzer, A., Brühl, C., Buchholz, J., Ganzeveld, L., Hoor, P., Kerkweg, A., and Lawrence, M.: The atmospheric chemistry general circulation model ECHAM5/MESSy: consistent simulation of ozone from the surface to the mesosphere, Atmos. Chem. Phys., 6, 5067-5104, doi:10.5194/acp-6-5067-2006, 2006.

Johnston, H. S. and Podolske, J.: Interpretations of Stratospheric Photochemistry, Rev. Geophys. Space Phys., 16, 491-519, 1978.

Jonsson, A. I., de Grandpre, J., Fomichev, V. I., McConnell, J. C., and Beagley, S. R.: Doubled $\mathrm{CO}_{2}$-induced cooling in the middle atmosphere: Photochemical analysis of the ozone radiative feedback, J. Geophys. Res., 109, D24103, doi:10.1029/2004JD005093, 2004.

Jonsson, A. I., Fomichev, V. I., and Shepherd, T. G.: The effect of nonlinearity in $\mathrm{CO}_{2}$ heating rates on the attribution of stratospheric ozone and temperature changes, Atmos. Chem. Phys., 9, 8447-8452, doi:10.5194/acp-9-8447-2009, 2009.
Jungclaus, J. H., Botzet, M., Haak, H., Keenlyside, N., Luo, J. J., Latif, M., Marotzke, J., Mikolajewicz, U., and Roeckner, E.: Ocean circulation and tropical variability in the coupled model ECHAM5/MPI-OM, J. Climate, 19, 3952-3972, doi:10.1175/JCLI3827.1, 2006.

LeTexier, H., Solomon, S., and Garcia, R. R.: The role of molecular hydrogen and methane oxidation in the water vapour budget of the stratosphere, Q. J. Roy. Meteorol. Soc., 114, 281-295, 1988.

Li, F., Austin, J., and Wilson, J.: The strength of the brewer-dobson circulation in a changing climate: coupled chemistry-climate model simulations, J. Climate, 21, 40-57, doi:10.1175/2007JCLI1663.1, 2008.

Li, Q., Graf, H.-F., and Giorgetta, M. A.: Stationary planetary wave propagation in Northern Hemisphere winter - climatological analysis of the refractive index, Atmos. Chem. Phys., 7, 183200, doi:10.5194/acp-7-183-2007, 2007.

McLandress, C., Jonsson, A. I., Plummer, D. A., Reader, M. C., Scinocca, J. F., and Shepherd, T. G.: Separating the Dynamical Effects of Climate Change and Ozone Depletion. Part I: Southern Hemisphere Stratosphere, J. Climate, 23, 5002-5020, doi:10.1175/2010JCLI3586.1, 2010.

Meul, S., Langematz, U., Oberländer, S., Garny, H., and Jöckel, P.: Chemical contribution to future tropical ozone change in the lower stratosphere, Atmos. Chem. Phys., 14, 2959-2971, doi:10.5194/acp-14-2959-2014, 2014.

Molina, M. J. and Rowland, F. S.: Stratospheric sink for chlorofluoromethanes: chlorine atomc-atalysed destruction of ozone, Nature, 249, 810-812, doi:10.1038/249810a0, 1974.

Nevison, C. D., Solomon, S., and Gao, R. S.: Buffering interactions in the modeled response of stratospheric $\mathrm{O}_{3}$ to increased $\mathrm{NO}_{x}$ and $\mathrm{HO}_{x}$, J. Geophys. Res.-Atmos., 104, 3741-3754, doi:10.1029/1998JD100018, 1999.

Nissen, K. M., Matthes, K., Langematz, U., and Mayer, B.: Towards a better representation of the solar cycle in general circulation models, Atmos. Chem. Phys., 7, 5391-5400, doi:10.5194/acp-75391-2007, 2007.

Oberländer, S., Langematz, U., and Meul, S.: Unravelling impact factors for future changes in the Brewer-Dobson Circulation, J. Geophys. Res.-Atmos., 118, 10296-10312, doi:10.1002/jgrd.50775, 2013.

Oman, L. D., Waugh, D. W., Kawa, S. R., Stolarski, R. S., Douglass, A. R., and Newman, P. A.: Mechanisms and feedback causing changes in upper stratospheric ozone in the 21st century, J. Geophys. Res., 115, D05303, doi:10.1029/2009JD012397, 2010.

Portmann, R. W. and Solomon, S.: Indirect radiative forcing of the ozone layer during the 21 st century, Geophys. Res. Lett., 34, L02813, doi:10.1029/2006GL028252, 2007.

Revell, L. E., Bodeker, G. E., Smale, D., Lehmann, R., Huck, P. E., Williamson, B. E., Rozanov, E., and Struthers, H.: The effectiveness of $\mathrm{N}_{2} \mathrm{O}$ in depleting stratospheric ozone, Geophys. Res. Lett., 39, L15806, doi:10.1029/2012GL052143, 2012.

Rind, D., Jonas, J., Stammerjohn, S., and Lonergan, P.: The Antarctic ozone hole and the Northern Annular Mode: A stratospheric interhemispheric connection, Geophys. Res. Lett., 36, L09818, doi:10.1029/2009GL037866, 2009.

Roeckner, E., Brokopf, R., Esch, M., Giorgetta, M., Hagemann, S., Kornblueh, L., Manzini, E., Schlese, U., and Schulzweida, U.: Sensitivity of Simulated Climate to Horizontal and Vertical 
Resolution in the ECHAM5 Atmosphere Model, J. Climate, 19, 3771-3791, doi:10.1175/JCLI3824.1, 2006.

Rosenfield, J. E. and Douglass, A. R.: Doubled $\mathrm{CO}_{2}$ Effects on $\mathrm{NO}_{y}$ in a Coupled 2D Model, Geophys. Res. Lett., 25, 4381-4384, 1998.

Rosenfield, J. E., Douglass, A. R., and Considine, D. B.: The impact of increasing carbon dioxide on ozone recovery, J. Geophys. Res.-Atmos., 107, ACH 7-1-ACH 7-9, doi:10.1029/2001JD000824, 2002.

Sander, R., Kerkweg, A., Jöckel, P., and Lelieveld, J.: Technical note: The new comprehensive atmospheric chemistry module MECCA, Atmos. Chem. Phys., 5, 445-450, doi:10.5194/acp-5445-2005, 2005.

Shepherd, T. G. and Jonsson, A. I.: On the attribution of stratospheric ozone and temperature changes to changes in ozonedepleting substances and well-mixed greenhouse gases, Atmos. Chem. Phys., 8, 1435-1444, doi:10.5194/acp-8-1435-2008, 2008.

Schultz, M. G., Backman, L., Balkanski, Y., Bjoerndalsaeter, S., Brand, R., Burrows, J. P., Dalsoeren, S., de Vasconcelos, M., Grodtmann, B., Hauglustaine, D. A., Heil, A., Hoelzemann, J. J., Isaksen, I. S. A., Kaurola, J., Knorr, W., LadstaetterWeißenmayer, A., Mota, B., Oom, D., Pacyna, J., Panasiuk, D., Pereira, J. M. C., Pulles, T., Pyle, J., Rast, S., Richter, A., Savage, N., Schnadt, C., Schulz, M., Spessa, A., Staehelin, J., Sundet, J. K., Szopa, S., Thonicke, K., van het Bolscher, M., van Noije, T., van Velthoven, P., Vik, A. F., and Wittrock, F.: REanalysis of the TROpospheric Chemical Composition over the Past 40 Years (RETRO) - a Long-term Global Modeling Study of Tropospheric Chemistry, Final Report, Jülich, Hamburg, Germany, August 2007.

Solomon, S., Garcia, R. R., Rowland, F. S., and Wuebbles, D. J.: On the depletion of Antarctic ozone, Nature, 321, 755-758, doi:10.1038/321755a0, 1986
Stolarski, R. S., Douglass, A. R., Newman, P. A., Pawson, S., and Schoeberl, M. R.: Relative Contribution of Greenhouse Gases and Ozone-Depleting Substances to Temperature Trends in the Stratosphere: A Chemistry-Climate Model Study, J. Climate, 23, 28-42, doi:10.1175/2009JCLI2955.1, 2010.

Waugh, D. W., Strahan, S. E., and Newman, P. A.: Sensitivity of stratospheric inorganic chlorine to differences in transport, Atmos. Chem. Phys., 7, 4935-4941, doi:10.5194/acp-7-4935-2007, 2007.

Waugh, D. W., Oman, L., Kawa, S. R., Stolarski, R. S., Pawson, S., Douglass, A. R., Newman, P. A., and Nielsen, J. E.: Impacts of climate change on stratospheric ozone recovery, J. Geophys. Res., 36, L03805, doi:10.1029/2008GL036223, 2009.

Wilcox, L. J., Charlton-Perez, A. J., and Gray, L. J.: Trends in Austral jet position in ensembles of high- and lowtop CMIP5 models, J. Geophys. Res.-Atmos., 117, D13115, doi:10.1029/2012JD017597, 2012.

WMO - World Meterological Organization: Scientific Assessment of Ozone Depletion: 2006, Global Ozone Research and Monitoring Project, Report Nr. 50, Geneva, Switzerland, 2007.

Wuebbles, D. J. and Hayhoe, K.: Atmospheric methane and global change, Earth-Sci. Rev., 57, 177-210, doi:10.1016/S00128252(01)00062-9, 2002.

Yang, P. and Brasseur, G. P.: The Nonlinear Response of Stratospheric Ozone to NOx and ClOx Perturbations, Geophy. Res Lett., 28, 717-720, 2001.

Zubov, V., Rozanov, E., Egorova, T., Karol, I., and Schmutz, W.: Role of external factors in the evolution of the ozone layer and stratospheric circulation in 21st century, Atmos. Chem. Phys., 13, 4697-4706, doi:10.5194/acp-13-4697-2013, 2013. 